\title{
Improvement of Student Learning Outcomes in Analysis of Heavy Standard Units Through Model Problem Based Learning Assisted with Audio Visual Media
}

\section{Selvia Dwi Ariyanti}

SD Negeri 3 Dermaji

selviadwiariyanti@gmail.com

\section{Article History}

accepted $14 / 11 / 2020$

\begin{abstract}
This study aims to improve student learning outcomes in analyzing the standard unit of weight through the model Problem Based Learning assisted by media audio-visual. The research was carried out using a model problem-based learning which is carried out in stages, namely through cycle I and cycle II, each cycle consisting of planning, implementing, observing, and reflecting stages. Data collection techniques using observation and tests. Data analysis used descriptive comparative analysis method. From this research, it can be seen that the learning outcomes of students in learning Mathematics in standard units of weight are increasing. This is evidenced by the learning outcomes obtained, namely the percentage of learning completeness in the first cycle of $37.5 \%$, in the second cycle the percentage of learning completeness is $93.5 \%$. The conclusion of this research is to use a model problem based learning assisted by audio visual media can improve mathematics learning outcomes standard unit of weight in class III students.
\end{abstract}

Keywords: Problem based learning, outcomes, weight standard unit.

\section{Abstrak}

Penelitian ini memiliki tujuan untuk meningkatkan hasil belajar peserta didik dalam menganalisis satuan baku berat melalui model Problem Based Learning berbantuan media audio visual. Pelaksanaan penelitian dilakukan menggunakan model problem based learning yang dilaksanakan secara bertahap, yaitu melalui siklus I dan siklus II, setiap siklus terdiri tahap perencanaan, pelaksanaan, observasi, dan refleksi. Teknik pengumpulan data menggunakan observasi dan test. Analisis data menggunakan metode analisis deskriptif komparatif. Dari penelitian ini dapat diketahui hasil belajar peserta didik dalam pembelajaran Matematika satuan baku berat semakin meningkat. Hal ini dibuktikan dari hasil belajar yang diperoleh yaitu persentase ketuntasan belajar pada siklus I 37,5\%, pada siklus II persentase ketuntasan belajarnya $93,5 \%$. Kesimpulan dari penelitian ini adalah dengan menggunakan pembelajaran model problem based learning berbantuan media audio visual dapat meningkatkan hasil belajar Matematika satuan baku berat pada peserta didik kelas III.

Kata kunci: Problem based learning, hasil belajar, satuan baku berat.

Social, Humanities, and Education Studies (SHEs): Conference Series https://jurnal.uns.ac.id/shes

p-ISSN 2620-9284

e-ISSN 2620-9292 


\section{PENDAHULUAN}

Matematika merupakan suatu disiplin ilmu bertujuan untuk mengasah kemampuan peserta didik dalam memahami dan mengaplikasikan konsep matematika , menggunakan penalaran, memecahkan masalah, serta mengomunikasikan gagasan, di samping juga untuk menghargai kegunaan matematika dalam kehidupan. Seiring perkembangan ilmu pengetahuan dan teknologi telah membawa perubahan yang sangat signifikan terhadap dimensi kehidupan manusia baik dalam ekonomi sosial budaya maupun pendidikan. Penggunanaan media pada pembelajaran matematika merupakan proses dan upaya guru dalam mengajarkan matematika terhadap peserta didik dalam rangka mencapai tujuan tertentu. Hal ini dilakukan dalam suatu lingkungan pendidikan karena matematika menjadi momok dan mata pelajaran yang tidak diminati peserta didik. Oleh karena itu guru harus mampu menerapkan model pembelajaran yang bisa memudahkan peserta didik dalam memahami materi yang disampaikan. Selain itu proses pembelajaran matematika sebaiknya dilakukan secara aktif, inovatif, efektif dan efisien, dengan menggunakan media yang tepat sehingga tujuan pembelajaran bisa dicapai dengan mudah.

Selama pandemi guru dalam memberikan pembelajaran kepada peserta didik hanya menggunakan media pembelajaran melalui whatsapp saja sehingga anak merasa bosan dan kurang antusias dalam mengikuri pelajaran. Berdasarkan pengalaman tersebut setelah peneliti melakukan observasi pelaksanaan pembelajaran dari 16 peserta didik yang ada di kelas III SD Negeri 3 Dermaji, hanya tiga peserta didik yang mencapai kriteria ketuntasan minimum. Rata-rata nilai ulangan harian yang didapat hanya 57,5 dari batas minimal yang ditentukan sekolah 75 . Berdasarkan evaluasi tersebut, diskusi teman sejawat, serta membaca beberapa referensi maka guru memandang problem based learning dapat menjadi solusi yang tepat dari permasalah-permasalahan di atas. Soucisse dkk (dalam baden dkk, 2004:28) mengatakan bahwa Problem Based Learning adalah sebuah cara untuk membuat peserta didik mengambil alih tanggung jawab dalam pembelajaran mereka sendiri, sehingga keuntungan yang mereka dapat lebih luas cakupannya dan mereka bisa menyalurkan serta menambah kemampuannya seperti kemampuan berkomunikasi,kerja tim serta memecahkan masalah. Dari pengertian tersebut metode problem based learning jelas sudah sejalan dengan prinsip inovatif learning dalam pembelajaran kurikulum 2013.

Berdasarkan latar belakang masalah, identifikasi masalah, dan analisis masalah tersebut maka peneliti dapat merumuskan masalah sebagai berikut: Apakah penerapan model Problem Based Learning berbatuan media audio visual dapat meningkatkan keterampilan peserta didik dalam menganalisis satuan baku berat di Kelas III SD Negeri 3 Dermaji Tahun Pelajaran 2020/2021?

Melalui rumusan masalah yang telah dikemukakan peneliti maka tujuan penelitian tindakan kelas ini dalah meningkatkan hasil belajar peserta didik dalam menganalisis satuan baku berat melalui model Problem Based Learning berbatuan media audio visual.

\section{METODE}

Penelitian ini merupakan penelitian tindakan kelas (PTK) yang dilaksanakan melaui dua siklus, setiap siklus terdiri tahap perencanaan, pelaksanaan, observasi, dan refleksi. Subjek penelitian ini adalah peserta didik kelas III SD Negeri 3 Dermaji tahun pelajaran 2020/2021 yang berjumlah 16 peserta didik. Penelitian ini dilaksanakan tanggal 16 November 2020 untuk siklus I dan tanggal 23 November 2020 untuk siklus II. Data yang dianalisis berupa data kuantitatif yaitu hasil belajar peserta didik dan data kualitatif berupa lembar observasi selama pembelajaran berlangsung. Teknik pengumpulan data menggunakan tes dan observasi. Analisis data menggunakan metode analisis deskriptif komparatif, yaitu dengan membandingkan hasil nilai tes awal 
dengan nilai peserta didik yang diperoleh pada masing-masing siklus dengan menggunakan google form.

\section{HASIL DAN PEMBAHASAN}

Setelah peneliti melakukan analisis dan perbaikan pembelajaran pada siklus I dan siklus II, pemahaman peserta didik dalam pelajaran Matematika satuan baku berat dengan menggunakan model pembelajaran problem based learning berbantuan media audio visual menunjukkan peningkatan hasil belajar peserta didik pada setiap siklusnya. Berdasarkan hasil pengamatan dari pelaksanaan perbaikan pembelajaran baik pada prasiklus, siklus I dan Siklus II tentang hasil belajar siswa dapat dilihat pada Gambar 1 Diagram Batang Hasil Belajar Peserta Didik pada Prasiklus, Siklus I dan Siklus II di bawah ini.

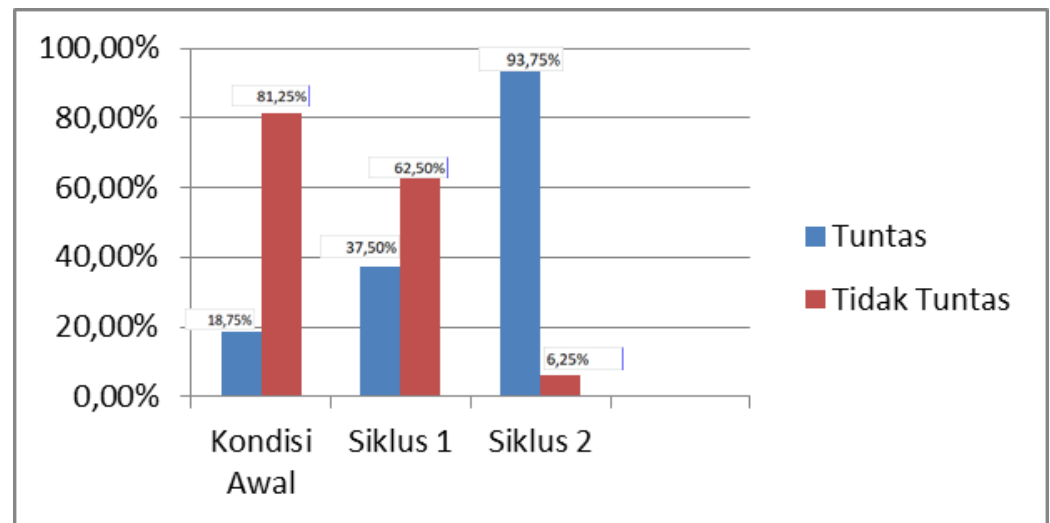

\section{Gambar 1. Diagram Batang Hasil Belajar Peserta Didik pada Prasiklus, Siklus I dan Siklus II}

Peningkatan hasil belajar peserta didik dalam menganalisis satuan baku berat menggunakan model problem based learning berbantuan media audio visual dapat diuraikan bahwa hasil belajar peserta didik kelas III SD Negeri 3 Dermaji dalam menyelesaikan evaluasi pembelajaran berbasis CBT mata pelajaran Matematika diperoleh hasil sebelumnya yaitu 13 dari 16 peserta didik belum mencapai KKM dengan persentase ketuntasan belajar hasil belajar hanya $18,75 \%$. Setelah dilakukan tindakan 6 dari 16 peserta didik mepmeroleh nilai diatas KKM dengan persentase hasil belajar mengalami peningkatan menjadi $37,50 \%$ pada siklus II ketuntasan hasil belajar peserta didik mencapai nilai diatas KKM dengan persentase 93,75\%.

Berdasarkan analisis hasil belajar peserta didik setelah pelaksanaan tindakan, dapat diambil kesimpulan bahwa penggunaan model problem based learning berbantuan media audio visual meningkatkan hasil belajar peserta didik dalam menganalisis satuan baku berat di kelas III SD Negeri 3 Dermaji secara signifikan sehingga peneliti merasa cukup dalam melaksanakan penelitian tindakan kelas. Hal ini juga didukung oleh pendapat Ibrahim dan Nur (Trianto, 2011: 96) bahwa pembelajaran berbasis masalah tidak dirancang untuk membantu guru memberikan banyak informasi kepada siswa, tetapi untuk membantu siswa mengembangkan kemampuan berpikir, pemecahan masalah, keterampilan intelektual, mempelajari peran orang dewasa juga belajar mandiri dan mandiri. Melalui PBL yang diterapkan diharapkan siswa dalam proses pembelajaran di kelas, dapat menumbuhkan keterampilan komunikasi matematis dan mampu membentuk kepribadian siswa menjadi belajar mandiri dalam berbagai masalah yang dihadapi siswa. PBL juga mencoba membantu siswa untuk menjadi pembelajar mandiri dan diatur sendiri, dibimbing oleh guru yang selalu memberikan semangat dan penghargaan ketika mereka mengajukan pertanyaan dan menemukan solusi 
mereka sendiri untuk masalah nyata, akankah siswa belajar untuk melakukan pekerjaannya secara mandiri.

\section{SIMPULAN}

Penggunaan model Problem Based Learning berbantuan media audio visual mampu meningkatkan hasil belajar peserta didik dalam menganalisis satuan baku berat di kelas III SD Negeri 3 Dermaji yang dilaksanakan melalui tahapan PBL yaitu: 1) Mengorientasikan siswa pada masalah, 2) Mengorganisasikan siswa untuk belajar, 3) Mengorganisasikan siswa untuk belajar, 4) Mengembangkan dan menyajikan hasil karya, 5) Menganalisis dan mengevaluasi proses pemecahan masalah. Melalui pemilihan model yang tepat dan penggunaan media yang tepat dapat meningkatkan motivasi dan minat peserta didik dalam proses pembelajaran. Selain itu model PBL dapat membantu peserta didik dalam pemecahan masalah sehingga peserta didik belajar keterampilan-keterampilan melalui penyelidikan dan berpikir sehingga dapat memandirikan peserta didik dalam belajar dan memecahkan masalah.

\section{DAFTAR PUSTAKA}

Arikunto, Suharsimi. (2006). Penelitian Tindakan Kelas. Jakarta : PT. Bumi aksara Arrends. (1997). Design Instructional. New York: Macmilan College Publishing Company.

Daryanto. (2013). Media Pembelajaran: Perananya Sangat Penting Dalam Mencapai Tujuan Pembelajaran. Yogyakarta: Gava Media.

Sudjana, Nana. (2012). Penilaian Hasil Proses Belajar Mengajar. Bandung: Remaja Rosdakarya

Winataputra, Udin S. dkk. (2008). Teori Belajar dan Pembelajaran. Jakarta: Universitas Terbuka.

W, Sri Anitah, dkk. (2011). Modul 1. Hakikat Strategi Pembelajaran. Strategi Pembelajaran di SD. Jakarta: Pusat Penerbit Universitas Terbuka. 